\title{
SARS-COV-2 VACCINATION AND EMPLOYMENT: THE LEGAL FRAMEWORK IN THE EU AND HUNGARY
}

Accepted
01. 08. 2021
Revised
25. 08. 2021
Published
29. 10. 2021

Keywords

vaccination

obligation,

workplace

safety,

employee

rights,

EU

action,

Hungarian

law

\section{Mária Eva Földes ${ }^{1}$ \& Csilla Kaposvári ${ }^{2}$}

1 The Hague University of Applied Sciences, International and European Law Program and Center of Expertise on Global Governance, Den Haag, The Netherlands.

E-mail: e.m.foldes@hhs.nl.

${ }^{2}$ University of Pécs, Faculty of Health Sciences, Doctoral School, Pécs, Hungary. E-mail:kacsilla@yahoo.com.

CORRESPONDING AUTHOR e.m.foldes@hhs.nl.

Abstract The paper explores whether and under what conditions, vaccination against SARS-CoV-2 may become a mandatory requirement for employees. It includes a discussion on EU action on SARS-CoV-2 vaccination and its relevance for national level policy with emphasis on the legal basis and instruments used by the Union to persuade national authorities into action to increase vaccination uptake. The analysis then moves to the national level by focusing on the case of Hungary. Following an overview of the legal and regulatory framework for SARS-CoV-2 vaccines deployment, the analysis zooms into the sphere of employment and explores whether and how the SARS-CoV-2 vaccination may be turned into a mandatory workplace safety requirement. The paper highlights the decision of the Hungarian government to introduce compulsory vaccination for employees in the healthcare sector, and concludes with a discussion of the relevant rules and their potential, broader implications. 


\section{$1 \quad$ Introduction}

Deployment of vaccines against severe acute respiratory syndrome coronavirus 2 (hereafter: SARS-CoV-2) has sparked the debate on steps that diverse actors like international organizations, supranational institutions, national authorities, and (public and private) employers, may lawfully take to ensure that the vaccination policies and programs achieve their desired compliance level. In many countries worldwide, scaling up the vaccination of the population has become a priority in the fight against the SARS-CoV-2 pandemic. A highly controversial issue is whether public and/or private actors should - and lawfully could - make vaccination against SARS-CoV-2 mandatory, by regulation and/or under employment terms. This has prompted the discussion about individuals' freedom of choice and right to (refuse) consent.

People have challenged mandatory vaccination policies and practices on the basis of human rights law as well as under labour law. Human rights-based challenges have mainly focused so far on mandatory vaccination of children, and materialized in attempts of parents to invoke consent, privacy rights and the freedom of thought, conscience, and religion when contesting compulsory vaccination rules adopted by national governments ${ }^{1}$. In some cases, adults have challenged compulsory vaccination on the basis of the right to respect for private life, which includes a person's bodily integrity. ${ }^{2}$ Examples for labour law-based challenges include healthcare workers' attempts to contest mandatory vaccination against seasonal epidemics such as influenza. Labour arbitrations have been prominent in case of the latter (Gruben, Siemieniuk \& McGreer, 2014; Flood, Thomas \& Wilson, 2021).

\footnotetext{
${ }^{1}$ See for example, V avricke a and others $v$. the Czech Republic (application no. 47621/13) and five additional, related applications lodged with the European Court of Human Rights between 2013 and 2015 challenging the Czech legislation on compulsory vaccination and its consequences for those who refuse to comply with it. The applicants relied on Article 8 (the right to respect for privacy and family life) and Article 9 (freedom of thought, conscience and religion) of the European Convention on Human Rights and Fundamental Freedoms and Article 2 of its 1 st Protocol. In the European Union context, see Court of Justice of the European Union, C-459/13 Milica Široká v Úrad verejného zdravotnictva Slovenskej republiky, ECLI:EU:C:2014:2120.

${ }^{2}$ See for example Solomakhin v. Ukeraine (application no. 24429/03), in which the European Court of Human Rights ruled that compulsory vaccination - as an involuntary medical treatment - amounted to an interference with the right to respect for one's private life including a person's physical and psychological integrity, as guaranteed by Article 8 paragraph 1 of the European Convention on Human Rights and Fundamental Freedoms. However, as ruled by the Court, such interference may be justified if it is provided for by the law, it pursues the legitimate aim of the protection of health and is necessary in a democratic society.
} 
The sphere of employment is of particular interest in the dispute about making SARS-CoV-2 vaccines compulsory. A highly contagious virus that can make employees seriously ill and unable to work for a longer time period might prompt employers to consider measures that ensure high vaccination rates among the workers. Apart from economic and financial interests that motivate measures to reduce absenteeism, liability concerns and occupational safety considerations might also motivate such measures. It is indeed the duty of employers to ensure a safe and healthy working environment. Moreover, employers in certain work places such as care homes, healthcare facilities, schools and so on, must also protect the health and safety of service recipients and clients.

The introduction of mandatory vaccination in the context of employment is not without precedent in the European Union countries. A number of Member States have made vaccination mandatory for workers in the healthcare sector. For example, Italy made vaccination against SARS-CoV-2 mandatory for healthcare workers in an emergency decree adopted on 1 April 2020. According to this decree, health professionals who refuse to take the vaccine shall either be tranferred to other duties with no risk of transmission or be suspended for a year (Paterlini, 2020). In France, all healthcare workers must get vaccinated against SARS-CoV-2 according to the rules announced on 12 July 2021 by President Emmanuel Macron. Healthcare workers must be fully vaccinated by 15 September 2021, otherwise their payment will be suspended (Wise, 2021). Greece made vaccination compulsory for nursing home workers on 12 July 2021 with immediate effect (Reuters, 2021). Vaccination against SARS-CoV-2 has also been intensively promoted at the European Union level. Although the EU does not have the legal competence to impose a vaccination obligation, it has been using other instruments to promt national governments into action to increase vaccination coverage and meet common targets.

A number of questions arise in this context: May employers legally justify imposing a SARS-CoV-2 vaccination obligation on their employees? For example, if employers' attempts at voluntary vaccination programs do not achieve their desired compliance level, can they enforce workers' participation in such programs? Can they make this a hiring requirement, a condition for fulfilling certain positions or awarding bonuses, promotions, benefits? Specifically, can employers use occupational health and safety rules as a legal basis for justifying such decisions? Are employees entitled to exemptions and on what grounds? How can the law protect 
employees' rights in such cases? And, should rules for mandatory vaccination of workers be left to the discretion of private actors such as employers?

The paper intends to contribute to this debate by analysis conducted at two levels. It starts with a discussion of European Union-level action on SARS-CoV-2 vaccination and its relevance for national level policy. Despite a narrowly constructed legal basis in public health, the EU has used a range of instruments to promote vaccination uptake and set common coverage targets for national authorities. The analysis lays particular emphasis on the legal bases and tools used by the EU to persuade national authorities into action to increase vaccination uptake among the population. Relevance of EU occupational health and safety law is also discussed.

Afterwards, the analysis moves to the national level by focusing on the case of Hungary, a Member State of the European Union where vaccination against SARSCoV-2 became available for the population in December 2020. Originally, the Hungarian government has stated its intentions to keep the SARS-CoV-2 vaccination voluntary for all individuals. However, in July 2021, the government made use of its special powers under the state of danger in place since March 2020, and adopted a decree imposing a vaccination obligation on workers in the healthcare sector. Following an overview of Hungary's existing policies on immunization, the analysis proceeds with the country's legal and regulatory framework for SARS-CoV2 vaccines deployment. It then zooms into the sphere of employment and explores whether and how the SARS-CoV-2 vaccine could be turned into a mandatory workplace safety requirement.

\section{European Union action on SARS-CoV-2 vaccination: competences, legal basis, and instruments}

In the European Union, vaccination policy has been traditionally understood as a competence reserved for Member States' authorities as part of national public health policy. Although the Treaty on the Functioning of the European Union (Treaty of Lisbon, 2007, hereafter: TFEU) provides the Union with a legal mandate for taking various types of action in public health, the legal basis internalizes the subsidiarity principle. Consequently, defining health policy, organizing and managing health systems and health care constitute areas falling within the Member States' 
competence. Article 168 TFEU requires the Union to refrain from superseding national action in these domains. ${ }^{3}$

However, as highlighted by scholars, notably, Purhhagen, De Ruijter, Flear, Hervey \& Herwig (2020: 297) a closer look at the health-related TFEU provisions, especially when read as linked to one another, reveals that the legal basis for Union action in public health is not as limited as is traditionally understood. The TFEU allows for a wide range of Union actions in public health in general and in the field of vaccination in particular. Union initiatives launched so far on SARS-CoV-2 vaccination show that where political will exists, the legal obstacles to Union action turn out to be less restrictive than anticipated. The following sections of this paper provide an overview of these Union initiatives and their relevance for national level policy and action.

\subsection{Union action under its coordinating, supporting, supplementing competence}

The TFEU empowers the Union to protect and improve human health and combat major health scourges. Towards this end, the Union shall take action that supplements, supports, or coordinates national health policies ${ }^{4}$. Article 168 TFEU on public health provides further details on such competences. Notably, the Court of Justice of the European Union emphasized in the Siroká judgment that Article 168 TFEU did not lay down any obligation relating to vaccination. This judgment was delivered in a dispute between Ms Široká and the Slovak Public Health Authorities concerning the former's refusal to comply with the obligation to have her minor child vaccinated. As ruled by the Court, Article 168 TFEU established no obligation that could be used to assess the conformity of national vaccination measures with EU law (Milica Široká v Úrad verejnébo zdravotnictva Slovenskej republiky, 2014).

\footnotetext{
${ }^{3}$ See, for a detailed discussion of the interplay between Member States' interests and European Union law in health care, Földes, 2019: 213-232.

4 Article 6 TFEU includes protection and improvement of human health among areas where the Union has coordinating, supporting, and supplementing competence.
} 
While measures that have as their primary objective the harmonization of national vaccination rules are explicitly excluded under Article 2(5) TFEU, Article 168 TFEU provides a mandate for transnational cooperation and a task for the Union to assist in the coordination of national policies and programs. This may involve non-binding (soft law) initiatives such as development of common strategies, coordination of national action, development of guidelines and indicators measuring progress, exchange of information, data and best practices, as well as periodic monitoring and evaluation of policies and programs.

The European Commission used the coordinating competences and corresponding soft law instruments to launch in June 2020 a pan-European SARS-CoV-2 vaccination strategy, to be implemented together with the Member States (European Commission Communication $\operatorname{COM}(2020) 245$ final, 2020; European Commission Communication $\operatorname{COM}(2020) 680$ final, 2020). The aim of the strategy is twofold: (1) securing vaccines supplies through the Advance Purchase Agreements concluded by the European Commission with individual manufacturers on behalf of the Member States, and (2) speeding up the development, authorization, and availability of vaccines while simultaneously ensuring their safety, quality, and efficacy. In January 2021, the Commission proposed a number of additional measures to speed up vaccination and ramp up the supply of vaccines and related information. It set common population coverage targets for the Member States. Accordingly, by March 2021, at least 80 percent of people over the age of 80 , and 80 percent of healthcare and social care professionals in every Member State, should be vaccinated. By summer 2021, Member States should vaccinate 70 percent of the entire adult population.

Furthermore, the European Commission initiated the development of a common European approach to vaccination documentation and mutual recognition, and the establishment of EU-wide vaccine safety and effectiveness studies. Additionally, it proposed to create an EU vaccine sharing mechanism with neighboring third countries and regions (European Commission Communication COM(2021) 35 final, 2021). Formally, all these are soft law initiatives and Member States are not legally bound to comply with the targets set therein. Although several elements of the strategy were still debated at the time of the writing of this paper, implementation has started with Union funds earmarked, as discussed further in section 2.4. below (incentive measures). 
It is notable that the harmonization prohibition inserted in Article 2(5) TFEU has not prevented the Union legislature in the past from adopting harmonizing measures with a public health protection objective. TFEU articles other than Article 168, have been used as legal bases in such instances. Examples include the internal market clause (currently, Article 114 TFEU) and the recent use of Article 21(2) TFEU on non-discrimination and citizenship of the Union. Notably, the latter was indicated as the legal basis for adopting the framework for the issuance, verification and acceptance of interoperable COVID-19 vaccination, test, and recovery certificates (EU Digital COVID Certificate) to facilitate free movement during the COVID-19 pandemic (Regulation (EU) 2021/953 of the European Parliament and of the Council, 2021).

In the past, the Court of Justice of the European Union (CJEU) ruled that internal market measures ${ }^{5}$ that had an effect of protecting and/or improving human health, could be lawfully adopted by the Union as long as such measures removed trade impediments or eliminated appreciable distortions of competition (Federal Republic of Germany v. European Parliament and Council (Tobacco Advertising), 1998; Federal Republic of Germany v. European Parliament and Council, 2003). The CJEU upheld this even where public health protection was a demonstrably decisive factor in the legislative choices at issue (Poland v. Parliament and Council (Tobacco Products), 2014). It remains to be seen whether and how the Union will further use its legislative powers under the various TFEU clauses to adopt binding measures that impact on vaccination policy. In addition, the Union has a more direct law-making power in relevant public health fields, granted to it by Article 168 TFEU. The following section reviews this power and discusses how the Union has used it so far in the field of vaccination.

\subsection{Union action under the shared legislative and regulatory competence}

Although the TFEU has limited the Union's legislative and regulatory competence in public health, it has nevertheless conferred upon the Union direct law-making powers in a number of important health policy fields. Common safety concerns in public health matters are identified in Article 4 TFEU as an area of shared competence and the Union's related law-making powers are further specified in Article 168 TFEU. As a general rule applicable to areas of shared competence, the

\footnotetext{
${ }^{5}$ Adopted under Article 114 TFEU.
} 
Union enjoys priority in action, and the Member States shall exercise their competence to the extent that the Union has not done so or has ceased doing so (Article 2(2) TFEU).

Particularly relevant for vaccines is the Union's direct competence to legislate and adopt legally binding acts that set high standards of quality and safety for pharmaceutical products and medical devices (Article 168 TFEU). Thus, it has a legal basis to harmonize the requirements for the granting of marketing authorization and post-market monitoring of SARS-CoV-2 vaccines. The European Medicines Agency (EMA) is responsible for the independent scientific safety, efficacy, and quality assessment of the vaccines (Regulation (EC) No 726/2004 of the European Parliament and of the Council, 2004). The European Commission has been vested with the legal responsibility to adopt the marketing authorization decision. It grants the authorization further to the positive recommendation issued by the EMA's Committee for Medicinal Products for Human Use and the approval of a qualified majority of the Member States. It is the duty of the Commission to ensure patients' and health care professionals' access to all necessary information on vaccines, in all Member States in their national language.

To speed up the vaccine authorization process, the Union has put in place emergency regulatory tools such as the Conditional Marketing Authorization, which allow for a quick adoption of marketing authorizations, an accelerated approval process, and post-authorization monitoring and safeguards (Regulation (EC) No 726/2004 of the European Parliament and of the Council, 2004, Article 14(7). ${ }^{6}$ This procedure has been used during the pandemic as a fast-track for authorizing SARSCoV-2 vaccines and treatments. Pharmaceutical legislation adopted by the Union also allows for Emergency Use Authorization by the individual Member States. This enables the temporary distribution and use of an unauthorized or investigational vaccine under certain conditions, in the context of emergency circumstances, and under the sole responsibility of the authorizing Member State (Directive 2001/83/EC of the European Parliament and of the Council, 2001).

\footnotetext{
6 The rules on the granting of a Conditional Marketing Authorization are further specified in Commission Regulation (EC) No 507/2006 of 29 March 2006 on the conditional marketing authorization for medicinal products for human use falling within the scope of Regulation (EC) No 726/2004 of the European Parliament and of the Council. (2006). Official Journal of the European Union L92, p. 6-9.
} 
In some instances, the Union has temporarily eased or relaxed the standards and rules to facilitate vaccines development. For example, a Regulation ((EU) 2020/1043 of the European Parliament and of the Council) was adopted in July 2020 to allow for a temporary derogation from certain provisions of the Genetically Modified Organisms (GMOs) Directives 2001/18/EC and 2009/41/EC for clinical trials with SARS-CoV-2 vaccines that contain or consist of such organisms. The proposed derogation applies to the operations necessary for the clinical trial phase and for compassionate or emergency use in the context of the pandemic. Another example is the disapplication of the "one-time, last time" competition law principle to allow for the Member States' providing of state aid to the industry as a means to expand vaccine production capacity (European Commission, Communication C(2020) 1863 final, 2020; Communication C(2020) 2215 final, 2020).

It is also important to note that Article 153 TFEU provides the Union with a legal basis to adopt binding law on occupational health and safety. Consequently, the Union has adopted a number of instruments in this field, some of which include provisions relevant to vaccination. The following section discusses the relevance of these rules for SARS-CoV-2 vaccination.

\subsection{Relevance of EU occupational health and safety rules}

Pursuant to Article 153 TFEU, the Union legislature has adopted a number of binding and non-binding instruments in the field of occupational health and safety. Most of the binding EU rules - predominantly stipulated in directives - constitute minimum standards, which means that Member States are allowed to adopt stricter rules when transposing them into their national law to ensure a higher level of protection of workers. Some of the relevant EU instruments include provisions pertaining to the vaccination of workers. Notably, Directive 2000/54/EC on the protection of workers from risks related to exposure to biological agents at work addresses the issue of vaccination as part of the health surveillance of workers performing activities that potentially expose them to biological agents (Directive 2000/54/EC of the European Parliament and of the Council, 2000, p. 21). As set forth in Article 14 of Directive 2000/54/EC, employers should make available effective vaccines for those workers who are not yet immune to the biological agent to which they are exposed or are likely to be exposed. 
When fulfilling their obligation to ensure worker's access to vaccination, employers should take into account a recommended code of practice stipulated in Annex VII of Directive 2000/54/EC. The code of practice reiterates the obligation of employers to offer vaccination to workers whenever a risk assessment carried out in line with the provisions of the Directive reveals the existence of a health and safety hazard due to exposure to biological agents for which effective vaccines are available. Further on, the code specifies that national law and/or practice governs the conditions under which such vaccination should be carried out. It then lays down a number of general principles such as appropriate information provision to the workers concerned on the benefits and drawbacks of both vaccination and nonvaccination; offering the vaccination free of charge to the workers; and the possibility to draw up a vaccination certificate. This certificate should be made available to the workers concerned as well as the competent authorities, the latter being ensured upon request.

As discussed above, EU instruments on occupational health and safety emphasize the employers' duty to make effective, free of charge vaccination available for workers exposed to biological agents, and ensure appropriate information on the benefits and disadvantages of both vaccination and non-vaccination. At the same time, they refrain from imposing any vaccination obligation on the workers themselves, nor do they prescribe any requirement for the national governments to make vaccination compulsory in the context of employment. This is in line with the general competence division rule in the field of public health according to which, vaccination policy constitutes a national competence.

\subsection{Relevance of "incentive measures" enshrined in Article 168(5) TFEU}

Article 168(5) TFEU provides a legal basis for the Union legislator to adopt incentive measures to combat major cross-border health scourges, and monitor and combat serious cross-border health threats such as SARS-Cov-2. Harmonization is explicitly excluded but apart from that, both positive and negative "incentives" may be used. Pooling knowledge, skills, expertise and administrative capacity, joint procurement, access to funding and resources in a broader sense may be used as positive incentives. Exclusions from these might constitute negative incentives (see also Purhhagen, De Ruijter, Flear, Hervey \& Herwig, 2020, p. 302). 
During the pandemic, the Union has deployed its financial resources and mobilized various funding instruments and mechanisms to impact national level vaccination policies and programs. Articles 180 and 182 TFEU provide the legal basis for the Union funding of collaborative research into vaccines. Resources may also be pooled under a Civil Protection Mechanism based on Article 222 TFEU if endorsed by the Member States (Council Decision (EU) 2014/415, 2014). This mechanism permits the deployment of the Union's internal funds, pre-committed national funds, and co-financed capacities with Member States to respond to major emergencies. The Commission used this mechanism for the April 2020 activation of the Emergency Support Instrument (Council Regulation (EU) 2016/369, 2016 as amended by Council Regulation (EU) 2020/521, 2020, p. 3.), which currently covers the upfront costs faced by vaccines manufacturers under the Advance Purchase Agreements (European Commission Decisions C(2020) 4192 final, 2020 and C(2020) 9309 final, 2020). Other funding instruments such as the Structural Funds, have also been used to mobilize investments (European Commission, Proposal for a Regulation, $\operatorname{COM}(2020) 113$ final, 2020).

The potential and the limits of incentive measures as a basis for EU action constitute areas that call for more in-depth exploration. At this point, it is largely untested how far the Union could go under this legal basis to influence national vaccination policies. Harmonization is explicitly excluded in Article 168(5), which means that Union measures that would incentivize Member States to make vaccination mandatory would probably not pass legal scrutiny. Nevertheless, commentators point out that incentive measures might be combined with the Union's coordinating powers to persuade Member States into action (Purhhagen, De Ruijter, Flear, Hervey \& Herwig, 2020, p. 302). For example, positive or negative incentives might be used (e.g., in terms of increased access to shared resources or exclusion from those) to make national authorities reach the population coverage targets set in the common vaccination strategy.

Concerns have been voiced about the Commission's 'one-size-fits-all' approach to improving vaccination coverage (see, for example, the European Academies Science Advisory Council (EASAC) \& the Federation of European Academies of Medicine (FEAM), 2018; Paul \& Loer, 2019). The Council of Europe's Parliamentary Assembly urged in its resolution both the European Union and the Member States to "ensure that citizens are informed that the vaccination is not mandatory and that 
no one is politically, socially, or otherwise pressured to get themselves vaccinated, if they do not wish to do so themselves" (Council of Europe, 2021: par. 7.3.1). It also called on the Union and national governments to "ensure that no one is discriminated against for not having been vaccinated, due to possible health risks or not wanting to be vaccinated" (Council of Europe, 2021, par. 7.3.2). The resolution thus emphasized the responsibility of both the Union and national authorities to ensure that people are aware of the voluntary character of the SARS-CoV-2 vaccination, and their responsibility to protect from discrimination those individuals who chose not to or cannot be vaccinated.

As show by the above analysis, the EU has more competences and tools to influence national level vaccination policy than traditionally presumed. Although it presently lacks the legal power to make vaccination mandatory or prohibit Member States from doing so, it can nevertheless use its instruments, such as incentive measures, to persuade national authorities into action. The European Commission has called for enhanced transnational cooperation to increase vaccine uptake and set concrete population coverage targets to be achieved by all Member States. This includes specific - although formally non-binding - targets for vaccinating workers in the healthcare and social care sectors.

\section{SARS-CoV-2 vaccination in the context of employment: the case of Hungary}

The following part of this paper shifts the focus of the analysis to the national level by zooming on the case of Hungary, a Member State of the European Union.. The pandemic has posed various challenges to the Hungarian sotiety, and the health and legal policy responses have been discussed in recent publications (Sándor, 2020). Vaccination against SARS-CoV-2 became available in Hungary in December 2020. Originally, the Hungarian government promulgated its decision to keep the SARSCoV-2 vaccination voluntary for everybody irrespective of profession and employment. However, in July 2021, the Prime Minister of Hungary announced the intention of the government to turn vaccination into a mandatory requirement for healthcare professionals. On 30 July 2021, this materialized in a decree imposing mandatory vaccination on workers in the healthcare sector. The next sections of this paper focus on the Hungarian case and discuss SARS-Cov-2 vaccination in the context of employment. Following an overview of national legislation governing 
vaccination, the analysis explores how the SARS-CoV-2 vaccine could be turned into a mandatory workplace safety requirement and what the latest developments are in this field in Hungary.

\subsection{The Hungarian legal and regulatory framework for SARS-CoV-2 vaccines deployment in the context of employment}

In Hungary, vaccination policy is implemented according to the rules set in Parliamentary Act CLIV of 1997 on Health ${ }^{7}$, Parliamentary Act XLVII of 1997 on the management and protection of personal health data and related data ${ }^{8}$, Decree No. 18/1998. (VI. 3.) of the Minister of Welfare ${ }^{9}$, and Decree No. 61/1999. (XII. 1.) of the Minister of Health. ${ }^{10}$ In addition, employers must adopt health and safety measures at the workplace pursuant to the Hungarian Labour Code, 2012, Article 51.11 This may include vaccination as a means to ensure occupational and workplace safety.

Parliamentary Act CLIV of 1997 on Health (article 57(3)) and the Hungarian Labour Code (2012, article 88(2)) provide the legal basis for the adoption of ministerial decrees prescribing a vaccination obligation for certain categories of professions and employees as a condition for employment in case of specific jobs/positions. Ministerial decrees may also determine the list of the jobs concerned as well as the list of infectious diseases for which a vaccination obligation may be imposed depending on age and degree of health threat. This empowers the minister in charge of the health portfolio to adopt binding rules that prescribe, in case of specific professions/jobs, mandatory vaccination as a measure to reduce the risk of infection. In such cases, it is the employer's obligation to ensure the worker's vaccination as part of employment terms, and to cover the related costs. For employees exposed to biological agents posing health and safety risks, employers must offer the possibility of vaccination, which is in line with the relevant EU

\footnotetext{
7 1997. évi CLIV. törvény az egészségügyről (Hung.) (Parliamentary Act CLIV of 1997 on Health).

8 1997. évi XLVII. törvény az egészségügyi és a hozzájuk kapcsolódó személyes adatok kezelésérōl és védelméröl (Hung.) (Parliamentary Act XLVII of 1997 on the management and protection of personal bealth data and related data).

9 18/1998. (VI. 3.) NM rendelet a fertőző betegségek és a járványok megelőzése érdekében szükséges járványügyi intézkedésekröl (Hung.) (Decree No. 18/1998. (VI. 3.) of the Minister of Welfare on epidemiological measures necessary to prevent infectious diseases and epidemics).

${ }_{10}$ 61/1999. (XII. 1.) EüM rendelet a biológiai tényezők hatásának kitett munkavállalók egészségének védelméről (Hung.) (Decree No. 61/1999. (XII. 1.) of the Minister of Health, on the health protection for workers exposed to biological agents). 11 2012. évi I. törvény a munka törvénykönyvéről (Hung.) (Hungarian Labour Code).
} 
occupational health and safety rules discussed under section 2.3 of this paper. Furthermore, employers must carry out the risk assessment while simultaneously safeguarding individual rights and freedoms (Decree No. 61/1999. (XII. 1.), article 13). Pursuant to the Parliamentary Act CLIV of 1997 on Health (Article 58), individuals may be exempted from a vaccination obligation if their (current or foreseeable) underlying health conditions so require. Existence of such health conditions and the need to postpone/set aside the vaccination obligation are determined by the patient's doctor. Should such underlying health conditions cease to exist, the mandatory vaccination must be provided to the employee without delay.

Pursuant to Decree No. 18/1998. (VI. 3.) (Article 9(2)), the Hungarian National Public Health Center ${ }^{12}$ determines, in a yearly methodological communication, the list of the jobs concerned. It also formulates recommendations on national level implementation. Although it was expected that the 2021 communication issued by the Center would bring further clarifications concerning vaccination against SARSCoV-2 in the context of employment, the document did not address this topic (Nemzeti Népegészségügyi Központ, 2021). Instead, the Office of the Chief Medical Officer provided guidance in targeted circular letters to keep up with the rapidly changing pandemic situation.

\subsection{Recent Hungarian developments: mandatory SARS-CoV-2 vaccination for workers in the healthcare and social care sectors}

As of 25 August 2021, the number of people fully vaccinated against SARS-CoV-2 reached 5,5 million (about 55 percent of the total population of Hungary). Following a continuous increase in the rates until May 2021, vaccination against SARS-CoV-2 has been stagnating since then among the general population. Six vaccines have been available, also including Sputnik V (Gam-COVID-Vac), which has been used in Hungary since March $2021^{13}$ although its authorization by the European Medicine

\footnotetext{
12 Nemzeti Népegészségügyi Központ, i.e., the National Public Health Center is part of the National Public Health and Medical Officer Service (NPHMOS), which consists of the Office of the Chief Medical Officer, and the national institutes: the National Public Health Center, the National Center for Epidemiology, the Institute for Emergency Healthcare Supply Management, and the National Institute for Health Development. It fulfills several functions such as scientific research and methodology setting, training, professional development and advice, supervision, and coordination.

13 See, for further details on the available vaccines, the website of the Hungarian Government dedicated to population information on the SARS-CoV-2 pandemic: https://koronavirus.gov.hu/cikkek/magyarorszagraerkezett-vakcinak-tipusa-es-mennyisege-7 (last accessed on 25 August 2021).
} 
Agency was still pending. The Delta variant of SARS-CoV-2 appeared in the country in June 2021. ${ }^{14}$ Since 1 August 2021, a third vaccine dose is available for individuals who have already been fully vaccinated.

In December 2020, when vaccination against SARS-CoV-2 became available in the country, the Hungarian government promulgated its decision to ensure that vaccination remained a voluntary choice of the individual, regardless of profession and employment status. However, mid-July 2021, the Hungarian Prime Minister announced in the media the decision to make SARS-CoV-2 vaccination mandatory for workers in the healthcare sector. ${ }^{15}$

In response to the announcement of the government, professional chambers representing Hungarian healthcare workers have expressed their support for the decision to make SARS-CoV-2 vaccination mandatory in their field. The Hungarian Chamber of Physicians welcomed the government's decision (Magyar Orvosi Kamara Elnöksége, 2021). ${ }^{16}$ The Chamber emphasized that vaccination against certain infectious diseases, such as Hepatitis B, had already been mandatory for Hungarian healthcare workers prior to the current pandemic. Although the Chamber had no official data on the number of healthcare workers vaccinated in Hungary, they stated in their communication that the vaccination rate among those workers was higher than among the general population.

Beyond the sphere of the healthcare sector, legal empowerment of employers to impose mandatory SARS-CoV-2 vaccination on workers has been advocated for by the Hungarian Chamber of Commerce and Industry. In July 2021, the Chamber was preparing a legislative amendment allowing for employers in diverse sectors to make vaccination mandatory for their respective employees ${ }^{17}$. According to the Chamber's proposal, this would be a requirement for certain positions and if an employee

14 The data have been communicated by the Hungarian government and are available at: https://koronavirus.gov.hu/cikkek/gulyas-ujabb-15-embernel-igazoltak-az-ujabb-virusvariansok-megjeleneset (last accessed on 25 August 2021).

15 Communication by the Hungarian Prime Minister on 16 July 2021: https://koronavirus.gov.hu/cikkek/orbanviktor-kormany-lehetove-teszi-harmadik-oltast, (last accessed on 25 August 2021).

${ }^{16}$ Magyar Orvosi Kamara Elnöksége, 2021, available at: https://mok.hu/hirek/mokhirek/a-magyar-orvosi-kamaraallaspontja-az-egeszsegugyben-dolgozok-kotelezo-covid-oltasaval-kapcsolatbanar (last accessed on 25 August 2021).

17 Interview given by the President of the Hungarian Chamber of Commerce and Industry, available at: https://www.portfolio.hu/gazdasag/20210720/uj-javaslat-erkezett-kotelezove-tehetne-a-munkahelyed-akoronavirus-oltast-493234 (last accessed on 25 August 2021). 
refuses, he/she could be moved to another position. As explained by the Chamber president in an interview given on 20 July $2021^{18}$, many employers have already been expecting their workers to vaccinate themselves, and were putting pressure on workers to comply with the vaccination targets. The Chamber president argued that acceptance of their proposal for amending the current legal framework would also clarify the sanctions that employers could lawfully use in case of non-compliance.

On 29 July 2021, the Hungarian government adopted a decree on mandatory SARSCoV-2 vaccination in the context of employment with a healthcare sector scope (Government Decree No. 449/2021. (VII. 29), hereafter the decree ${ }^{19}$ ). To adopt the decree, the government used its powers based directly on the Fundamental Law of Hungary (2011, Article 53(2)) according to which, "during a state of danger the government may issue decrees with which it may - according to the provisions laid down in a cardinal Act of Parliament - suspend the application of certain Acts of Parliament, derogate from the provisions laid down in Acts of Parliament or take other extraordinary measures". The decree entered into force on 1 August 2021. Upon termination of the state of danger, the decree will cease to have effect (pursuant to the Fundamental Law of Hungary, 2011, Article 53(4)).

The decree sets forth that as long as the state of danger persists (the latter being introduced in March 2021 as a response to the pandemic), healthcare service providers shall not employ nor hire any new employees who are not vaccinated against SARS-CoV-2. The scope is very large, including providers who operate in primary health care, on-call care, outpatient care, diagnostics, in-patient care, emergency care, patient transfer, healthcare provided in residential social or childcare institutions, armed forces and law enforcement bodies (primary care serving employees and prisoners), and in retail supply of medicines.

Pursuant to the decree, employers in the healthcare sector must request all workers who were not vaccinated prior to the entry into force of the decree, to take up the first vaccine dose until 1 September 2021, and the second dose within the period indicated by the vaccinating physician. Employers might request the workers to provide proof of their vaccination status and the workers must comply with this

\footnotetext{
${ }^{18}$ Ibid note 17.

19 449/2021. (VII. 29.) Korm. rendelet a koronavírus elleni védőoltás kötelező igénybevételéről (Hung). (Governmental Decree 449/2021. (VII. 29.) on mandatory vaccination against SARS-CoV-2).
} 
request within five days. National certificates, WHO-issued international certificates and EU Digital COVID Certificates are accepted as vaccination proofs.

The decree also specifies the sanctions for non-compliance. Notably, in the case of failing to comply with the vaccination obligation until the given deadline, or failing to provide a documented medical opinion that contraindicates the uptake of the vaccine, the employment must be terminated with immediate effect. Moreover, in such cases, the employee whose contract is terminated is not entitled to a notice period, nor to severance pay.

\subsection{SARS-CoV-2 vaccination at work: what employers can and must do}

As discussed above, vaccination against SARS-CoV-2 has become mandatory for Hungarian healthcare sector workers starting with 1 August 2021. This obligation lasts as long as the state of danger is in place (which was still the case at the time of completing this paper, meaning, as of 25 August 2021), and non-compliance is sanctioned with immediate termination of employment, lack of notice period, and no entitlement to severance pay. Furthermore, in August 2021, the Hungarian Chamber of Commerce and Industry was preparing a proposal for a legislative amendment that would also allow for employers in other sectors to impose a mandatory SARS-CoV-2 vaccination obligation on employees. According to the rules in force as of 25 August 2021, employers outside of the healthcare sector specified in the Government Decree 449/2021, were not allowed to use nonvaccination against SARS-CoV-2 as a reason for terminating the employment contract, depriving employers from a notice period and severance pay.

However, employers in other sectors might consider the use of incentive measures to pursue the vaccination targets. Such measures may fall into two broad categories: (1) negative incentives, i.e., prescribing a vaccination obligation for employees and enforcing it through sanctions and (2) positive incentives, i.e., rewarding employees who comply with the vaccination requirement. The goal of the latter is to persuade employees into compliance without making that formally mandatory. The following parts discuss the relevance of each incentive category and the related rules. 


\subsubsection{Use of negative incentives}

Negative incentives such as sanction applied in case of non-compliance, deprive employees of their de facto freedom of choice and consent. However, in certain cases, employers might lawfully constrain individual rights and freedoms in the context of employment and work. The Hungarian Labour Code allows for such constraints as long as they are necessary and proportionate (Hungarian Labour Code, Article 9(2)). A measure is "necessary" if it is indispensable for achieving an objective directly linked to the employment terms or for the protection of the rights and/or lawful interests of employers, employees or third parties (clients, business partners, service recipients, etc.). A measure is proportionate if it represents the least restrictive interference with individual rights and freedoms, taking into account the objectives pursued. ${ }^{20}$ Proportionality of the measure should always be assessed in the light of the applied sanctions. Whenever sanctions are applied, the employee's dignity should be protected. The latter constitutes the source of individual rights and freedoms and its protection is a fundamental and essential requirement, also in the context of work and employment (Kiss, 2010: 4).

When it comes to the enforcement of a vaccination obligation in the context of employment, sanctions imposed by employers and the related application of the necessity and proportionality standards have not been tested in Hungarian courts to this date (as of 25 August 2021). Commentators have argued that in the context of SARS-CoV-2, the necessity condition might be met due to the general pandemic situation, the resulting economic pressure on the employer, the protection of other employees who cannot be vaccinated due to their underlying health condition, and the protection of third parties such as service recipients (Társaság a Szabadságjogokért, 2021). However, these justifications are not automatically applicable to all employees. For example, it is questionable whether employees working in home office could be lawfully obliged to get vaccinated on the basis of the above-mentioned justifications. When it comes to proportionality, measures like regular testing or mandatory use of protective equipment might be deemed as a less restrictive interference compared to mandatory vaccination (Társaság a Szabadságjogokért, 2021). It is for the employer to prove that imposing a vaccination obligation is indeed the least restrictive measure.

\footnotetext{
${ }^{20}$ For further discussion on the necessity and proportionality tests and their application in Hungary, see GárdosOrosz, 2020: 9.
} 
Employers must comply with a number of requirements when imposing mandatory measures that limit individual rights and freedoms such as a vaccination obligation. As stated in the Hungarian Labour Code (Article 9(2)), they must inform employees in advance and in writing about the manner in which their individual rights and freedoms will be limited, the applicable conditions, the expected duration of the limitation, and the circumstances that show the fulfillment of the necessity and proportionality conditions.

Furthermore, pursuant to Article 9(3) of the Hungarian Labour Code, employees cannot waive their individual rights and freedoms in general terms. If an employer wants to waive his or her rights, only written legal statements are considered valid. In practice, the validity of such statements must always be examined on a case-bycase basis taking into account the power asymmetry in the employer-employee relationship and the broader context of such employee decisions.

\subsubsection{Use of positive incentives}

Employers might in principle consider several forms of positive incentives to persuade employees into compliance with the envisaged vaccination targets. However, such incentives should not result in the violation of the equal treatment requirement.

Article 12(1) of the Hungarian Labour Code stipulates the requirement of equal treatment in the context of employment. However, differential treatment might in some cases and under given circumstances, be justified and thus considered lawful in the sphere of work. The question is whether such differential treatment can be justified by a reasonable goal, which is directly linked to the employment terms. As pointed out by commentators, this reasonability test might be met in cases when measures seek to ensure health and safety at the workplace (Társaság a Szabadságjogokért, 2021). However, it is questionable whether incentives promoting vaccine uptake can be justified in working environments with no unavoidable direct contact between employees and/or employees and third parties (clients, business partners, service recipients...). It is also important to consider that some employees might have underlying health conditions that do not allow for their vaccination against SARS-CoV-2. Excluding such employees from positive incentives might amount to the violation of the equal treatment requirement. 
The issue of undue pressure also arises in case of positive incentives due to the power asymmetry characterizing the employer-employee relations (Társaság a Szabadságjogokért, 2021). Even in the absence of sanctions, employees might end up pressured into action to meet employee expectations and access benefits. To assess such cases, the necessity and proportionality tests should be applied on a caseby-case basis.

\section{$4 \quad$ Final remarks}

The SARS-CoV-2 pandemic has raised a number of questions related to who and under what conditions can a vaccination obligation be imposed on individuals. International organizations, supranational institutions such as the European Commission, Council and Parliament, national governments, public and private actors such as employers' repersentatives, have been involved in shaping the vaccination policy and influencing the related rights and obligations of individuals.

Vaccination against SARS-CoV-2 has been intensively promoted at the European Union level. Although the EU does not have a formal legal competence to impose a vaccination obligation nor to prohibit such measures, Union institutions have been using diverse provisions of the EU Treaties as a basis for action to promt national measures to increase vaccination coverage and meet common targets. When it comes to the context of work and employment, in EU law, SARS-CoV-2 vaccination has been emphazised as a right of the employee as well as an obligation of the employer to ensure access to it as an occupational safety measure.

At the national level, one can detect a tendency to shift the focus from employees' right to get vaccinated to their obligation to do so. Indeed, the introduction of mandatory vaccination in the context of employment is not without precedent in European Union countries as shown by examples from Italy, Greece, and France. These examples concern imposing a vaccination obligation on healthcare workers. A similar development has recently occured in Hungary. Although the original government narrative emphasized the voluntary character of SARS-CoV-2 vaccination, in July 2021, the Hungarian government used its special powers under the state of danger to adopt the rules on compulsory vaccination for workers in the healthcare sector. 
The Hungarian case has a number of noteworthy features. The rules on compulsory vaccination were adopted on the basis of the government's state of danger powers. Formally, this results in the temporary character of the rules, which would cease to apply simultaneously with the termination of the state of danger. Also, the adoption of the rules was based directly on the Fundamental Law's related provisions, and did not occur within the previously existing legal and regulatory framework of national level vaccination policy. The latter provides for a framework for defining certain professions/ positions for which compulsory vaccination would be imposed as well as the application of the necessity, proportionality, and reasonableness criteria derived from labour law if negative and positive incentives are used to ensure compliance of employees. Rather than following this framework, the government opted for a broader, sectoral approach, and imposed compulsory vaccination on all workers in the healthcare sector. In addition, the government decree does not mention any criteria such as necessity and proportionality; it simply imposes immediate termination of the employment contract, lack of notice period, and no access for employees to severance payment as direct sanctions for non-compliance. Pursuant to the newly introduced rules, employers in the healthcare sector have not only a legal basis to fire unvaccinated workers but also an obligation to do so. This means that practically, it has become impossible for workers in healthcare to refuse vaccination against SARS-CoV-2 unless they provide proof of medical contraindication.

So far, the Hungarian government has restricted compulsory SARS-CoV-2 vaccination to the healthcare sector workers. However, employers' representatives have seized the opportunity to advocate for an extension of this obligation to other sectors as well. Towards this end, the Hungarian Chamber of Commerce and Industry announced in July 2021 the preparation of a proposal for a legislative amendment that would provide the legal basis for employers to include mandatory vaccination in employment terms and to apply sanctions in case of non-compliance. Reaction of employee organizations is still pending. It remains to be seen whether the government will act on this proposal, and extend complusory vaccination of employees beyond the healthcare sector. It also remains to be seen whether the applicable sanctions would become more nuanced and explicitly linked to labour law principles such as necessity and proportionality. And, time will tell whether the new rules would pass scrutiny if tested in courts. 


\section{Legislation, Acts, Regulations and Court Decisions}

1997. évi CLIV. törvény az egészségügyről (Hung.) (Parliamentary Act CLIV of 1997 on Health).

1997. évi XLVII. törvény az egészségügyi és a hozzájuk kapcsolódó személyes adatok kezeléséről és védelméröl (Hung.) (Parliamentary Act XLVII of 1997 on the management and protection of personal health data and related data).

18/1998. (VI. 3.) NM rendelet a fertőző betegségek és a járványok megelőzése érdekében szükséges járványügyi intézkedésekről (Hung.) (Decree No. 18/1998. (VT. 3.) of the Minister of Welfare on epidemiological measures necessary to prevent infectious diseases and epidemics).

61/1999. (XII. 1.) EüM rendelet a biológiai tényezők hatásának kitett munkavállalók egészségének védelméről (Hung.) (Decree No. 61/1999. (XII. 1.) of the Minister of Health, on the bealth protection for workers exposed to biological agents).

2012. évi I. törvény a munka törvénykönyvéröl (Hung.) (Hungarian Labour Code).

449/2021. (VII. 29.) Korm. rendelet a koronavírus elleni védőoltás kötelező igénybevételéről (Hung). (Governmental Decree 449/2021. (VII. 29.) on mandatory vaccination against SARS-CoV-2).

Council Decision (EU) 2014/415 on the arrangements for the implementation by the Union of the solidarity clause. (2014). Official Journal of the European Union L192/53.

Council Regulation (EU) 2016/369 of 15 March 2016 on the provision of emergency support within the Union, Official Journal of the European Union L70, 2016, p.1, as amended by Council Regulation (EU) 2020/521 of 14 April 2020 activating the emergency support under Regulation (EU) 2016/369, and amending its provisions taking into account the COVID- 19 outbreak, Official Journal of the European Union L117, 15.4.2020, p. 3.

Council of Europe Parliamentary Assembly, Resolution 2361 (provisional version), text adopted by the Assembly on 27 January 2021 (5 $5^{\text {th }}$ Sitting).

Court of Justice of the European Union, Federal Republic of Germany v. European Parliament and Council (Tobacco Advertising), C-376/98, EU:C:2000:544.

Court of Justice of the European Union, Federal Republic of Germany v. European Parliament and Council, C380/03, EU:C:2006:772.

Court of Justice of the European Union, Poland v Parliament and Council (Tobacco Products), C-358/14, EU:C:2016:323.

Court of Justice of the European Union, Milica Široká v Úrad verejného zdravotnictva Slovenskej republiky, C459/13, ECLI:EU:C:2014:2120.

European Academies Science Advisory Council (EASAC) \& the Federation of European Academies of Medicine (FEAM). (2018). Addressing decreasing vaccine coverage in the EU. Editorial. The Lancet, 391, p. 1638.

European Commission, Regulation (EC) No 507/2006 of 29 March 2006 on the conditional marketing authorization for medicinal products for human use falling within the scope of Regulation (EC) No 726/2004 of the European Parliament and of the Council. (2006). Official Journal of the European Union L92, pp. 6-9.

European Commission, Communication from the Commission, EU strategy for COVID-19 vaccines, $\operatorname{COM}(2020) 245$ final, Brussels, 17.6.2020. See also European Commission, Communication from the Commission to the European Parliament and the Council, Preparedness for COVID19 vaccination strategies and vaccine deployment, $\operatorname{COM}(2020) 680$ final, Brussels, 15.10.2020.

European Commission, Communication from the Commission, Temporary Framework for State aid measures to support the economy in the current COVID-19 outbreak, C(2020) 1863 final, Brussels, 19.3.2020, Official Journal of the European Union C 91I/1; European Commission, Communication from the Commission, Amendment to the Temporary Framework for State aid measures to support the economy in the current COVID-19 outbreak, C(2020) 2215 final, Brussels, 3.4.2020.

European Commission, Commission Decision of 18.6.2020 approving the agreement with Member States on procuring Covid-19 vaccines on behalf of the Member States and related procedures, C(2020) 4192 final, Brussels, 18.6.2020. 
European Commission, Commission Decision of 15.12.2020 on implementing Advance Purchase Agreements on COVID-19 vaccines, C(2020) 9309 final, Brussels, 15.12.2020.

European Commission, Proposal for a Regulation of the European Parliament and of the Council amending Regulation (EU) No 1303/2013, Regulation (EU) No 1301/2013 and Regulation (EU) No 508/2014 as regards specific measures to mobilize investments in the healthcare systems of the Member States and in other sectors of their economies in response to the COVID-19 outbreak [Coronavirus Response Investment Initiative] COM(2020) 113 final.

European Commission, Communication from the Commission to the European Parliament, the European Council and the Council, A united front to beat COVID-19, COM(2021) 35 final, Brussels, 19.1.2021.

European Court of Human Rights, Solomakbin v. Ukraine (application no. 24429/03).

European Court of Human Rights, V avrickea and others v. the Czech Republic (application no. 47621/13).

European Parliament and Council, Directive 2000/54/EC of 18 September 2000 on the protection of workers from risks related to exposure to biological agents at work (seventh individual directive within the meaning of Article 16(1) of Directive 89/391/EEC). (2000). Official Journal of the European Union L262, p. 21.

European Parliament and Council, Directive 2001/83/EC of 6 November 2001 on the Community code relating to medicinal products for human use. (2001). Official Journal of the European Union L311, pp. 67-128.

European Parliament and Council, Directive 2001/18/EC of 12 March 2001 on the deliberate release into the environment of genetically modified organisms and repealing Council Directive 90/220/EEC - Commission Declaration (2001). Official Journal of the European Union L106, pp. 1-39; Directive 2009/41/EC of the European Parliament and of the Council of 6 May 2009 on the contained use of genetically modified micro-organisms (Recast) (2009). Official Journal of the European Union L125, pp. 75-97.

European Parliament and Council, Regulation (EC) No 726/2004 of 31 March 2004 laying down Community procedures for the authorization and supervision of medicinal products for human and veterinary use and establishing a European Medicines Agency. (2004). Official Journal of the European Union, L136, p. 1-33.

European Parliament and Council, Regulation (EU) 2020/1043 of 15 July 2020 on the conduct of clinical trials with and supply of medicinal products for human use containing or consisting of genetically modified organisms intended to treat or prevent coronavirus disease (COVID-19). (2020). Official Journal of the European Union L231, p. 12-16.

European Parliament and Council, Regulation (EU) 2021/953 of the European Parliament and of the Council of 14 June 2021 on a framework for the issuance, verification and acceptance of interoperable COVID-19 vaccination, test and recovery certificates (EU Digital COVID Certificate) to facilitate free movement during the COVID-19 pandemic. Official Journal of the European Union L 211, p. 1.

Magyarország Alaptörvénye, 2011. április 25. (Hung.) (Fundamental Law of Hungary, 25 April 2011).

Magyar Orvosi Kamara Elnöksége (2021). A Magyar Orvosi Kamara álláspontja az egészségügyben dolgozók kötelezó COVID oltásával kapcsolatban (Hung.) (Presidency of the Hungarian Chamber of Physicians. Position of the Hungarian Chamber of Physicians on compulsory COVID vaccination of workers in the healthcare sector), 16 July 2021. Available at: https://mok.hu/hirek/mokhirek/a-magyar-orvosi-kamara-allaspontja-az-egeszsegugybendolgozok-kotelezo-covid-oltasaval-kapcsolatban (last accessed on 25 August 2021).

Nemzeti Népegészségügyi Központ (2021). A Nemzeti Népegészségügyi Központ módszertani levele a 2021. évi védóoltásokról (Hung.), (National Public Health Center. Methodological communication on the 2021 vaccines). Available at:

https://www.antsz.hu/data/cms100122/VML_2021_NNK.pdf (last accessed on 25 August 2021).

Treaty of Lisbon amending the Treaty on European Union and the Treaty establishing the European Community [2007] Official Journal of the European Union C306/01. 
Website of the Hungarian Government dedicated to population information on the SARS-CoV-2 pandemic: https://koronavirus.gov.hu/cikkek/magyarorszagra-erkezett-vakcinak-tipusa-esmennyisege-7 (last accessed on 25 August 2021).

Website of the Hungarian Government dedicated to population information on the SARS-CoV-2 pandemic: https://koronavirus.gov.hu/cikkek/gulyas-ujabb-15-embernel-igazoltak-az-ujabbvirusvariansok-megjeleneset (last accessed on 25 August 2021).

Website of the Hungarian Government dedicated to population information on the SARS-CoV-2 pandemic: https://koronavirus.gov.hu/cikkek/orban-viktor-kormany-lehetove-tesziharmadik-oltast (last accessed on 25 August 2021).

Website: https://www.portfolio.hu/gazdasag/20210720/uj-javaslat-erkezett- kotelezove-tehetne-amunkahelyed-a-koronavirus-oltast-493234 (last accessed on 25 August 2021).

\section{References}

Flood, C.M., Thomas, B. \& Wilson, K. (2021) Mandatory vaccination for health care workers: an analysis of law and policy, Canadian Medical Association Journal, 193(6), pp. E217-E220, doi: $10.1503 /$ cmaj.202755.

Földes, M.É. (2019) Member State Interests and European Union Law: The Case of Health Policy and Health Systems, In: Varju, M. (ed), Between Compliance and Particularism: Member State Interests and European Union Law (Springer), pp. 213-232.

Gárdos-Orosz, F. (2020) Az alapjogok korlátozása, In: Könczöl, J. A., Menyhárd, M., Sulyok G. A. (eds.) Internetes Jogtudományi Enciklopédia, retrieved from: http://ijoten.hu/szocikk/azalapjogok-korltozsa (25 August 2021).

Gruben, V., Siemieniuk, R.A. \& McGreer, A. (2014) Health care workers, mandatory influenza vaccination policies and the law, Canadian Medical Association Journal, 186(14), pp. 1076-1080, doi: $10.1503 /$ cmaj.140035.

Kiss, GY. (2010) Alapjogok kollíriója a munkajogban (Pécs: Justis Tanácsadó Bt.)

Paterlini, M. (2020) On the front lines of coronavirus: the Italian response to Covid-19, BMJ, 368:m1065, doi: 10.1136/bmj.m1065 pmid:32179517.

Paul, K.T., \& Loer, K. (2019) Contemporary vaccination policy in the European Union: tensions and dilemmas, Journal of Public Health Policy, 40(2), pp. 166-179, doi: 10.1057/s41271-019-00163-8.

Purhhagen, K.P., De Ruijter, A., Flear, M.L., Hervey, T.K. \& Herwig, A. (2020) More Competences than You Knew? The Web of Health Competence for European Union Action in Response to the COVID-19 Outbreak, European Journal of Risk Regulation, 11(2), pp. 297-306, doi: 10.1017/err.2020.35.

Reuters (2021) Greece orders COVID-19 vaccinations as infections rise, Reuters, 12. 7. 2021, retrieved from: https://www.reuters.com/world/europe/greece-rolls-out-covid-19-vaccinationsthose-aged-15-17-2021-07-12/ (30 July 2021).

Sándor, J. (2020) Health and Legal Policy in Hungary at the Time of COVID-19 Pandemic. Medicine and Law, 39(2), pp. 191-202.

Társaság a Szabadságjogokért (2021) Így ösztönözhet jogszerủen az oltás beadására a munkáltató, TASZ, 10. 2. 2021, retrieved from: https://tasz.hu/cikkek/igy-osztonozhet-jogszeruen-azoltas-beadasara-a-munkaltato (25 August 2021).

Wise, J. (2021) Covid-19: France and Greece make vaccination mandatory for healthcare workers, BMJ, 374:n1797, doi: 10.1136/bmj.n1797. 